\title{
Karakteristik Fisiko-Kimia Konsentrat Protein Ikan Sunglir (Elagatis bipinnulatus)
}

\author{
Frets Jonas Rieuwpassaa* dan Eko Cahyonoa \\ aTeknologi Pengolahan Hasil Laut, Jurusan Perikanan dan Kebaharian, \\ Politeknik Negeri Nusa Utara
}

KATA K U N C I

etanol, ekstraksi, fisiko-

kimia, konsentrat protein ikan, sunglir

\begin{abstract}
A B S T R A K
Ikan merupakan sumber protein hewani yang memiliki daya cerna yang lebih baik dan jumlah kandungan asam amino essensial yang lebih banyak dibandingkan dengan sumber protein hewani lainnya. Ikan sunglir adalah jenis ikan pelagis yang banyak hidup diperairan Nusa Utara. Ekstraksi KPI umumnya dilakukan dengan menggunakan pelarut etanol. Penelitian ini bertujuan mengkarakterisasi sifat fisiko-kimia konsentrat protein ikan yang diekstrak dari ikan sunglir. Penggunaan etanol 90\% dalam mengekstraksi konsentrat protein dari ikan sunglir menghasilkan rendemen berkisar 18-20\%. Hasil Penelitian menunjukkan bahwa konsentrat protein ikan sunglir memiliki kandungan protein yang tinggi dan memiliki kadar lemak yang rendah. Konsentrat protein dengan kadar protein $>65 \%$ dan kadar lemak $<3 \%$ tergolong sebagai konsentrat protein Tipe B sesuai dengan standar Mutu FAO 1976 tentang KPI. Hasil pengujian fisik menunjukkan bahwa KPI memiliki kemampuan penyerapan air, lemak dan densitas kamba yang cukup baik untuk diaplikasikan ke dalam bahan pangan.
\end{abstract}

K E Y W O R D S

Ethanol, Extraction, Fish

Concentrate Protein,

Physicochemical properties,

Rainbow Runner

\section{A B S T R A C T}

Fish serve as an important source of animal protein with better digestibility and higher content of essential amino acids than other sources of animal protein. Elagatis bipinnulatus or sunglir in Indonesian is a common pelagic fish caught in Sangihe Islands. FPC is commonly extracted with etanol. Therefore, this research aims to characterise the physicochemical properties of the FPC extracted from rainbow runner. The use of $90 \%$ ethanol for exraction of FPC from rainbow runner resulted in $18-20 \%$ yield. The result shows that the local rainbow runner contained FPC with high level of protein $(77.34 \%)$ but low level of fat (1.22\%), classified as type B on the basis of FAO's standard on FPC Protein, which stipulated FPC with $>65 \%$ protein and $<3 \%$ fat content as Type B. In addition, physical analysis proved that FPC has appropriate water and fat absorption abilities as well as kamba density, suitble for food substitute or fortification.
TERSEDIA ONLINE

31 Okotober 2019

\section{Pendahuluan}

Konsentrat protein ikan atau disingkat KPI adalah sediaan protein kering yang diekstrak dengan cara menghilangkan lemak dan air sehingga protein terkonsentrat (Ibrahim 2009; Rieuwpassa et al. 2013). Bentuk protein ini sudah dikenal sejak lama dan menjadi salah satu pilihan sediaan yang dapat dimanfaatkan sebagai bahan substitusi, fortifikasi maupun pengkayaan pada produk-produk yang rendah protein. Selain itu, bentuk kering juga memudahkan dalam penyimpanan, transportasi dan umur simpan yang lebih lama.

Ekstraksi KPI biasanya menggunakan pelarut organik seperti ethanol dan isopropyl alkohol. Rieuwpassa et al. (2013), Wiharja et al. (2013) dan Rieuwpassa et al. (2018) menggunakan ethanol untuk mengekstraksi dan menghasilkan KPI dengan kadar protein berkisar 70-80\%. Menurut FAO (1976) KPI dibagi menjadi 3 Tipe yaitu Tipe A dengan kadar protein

*Corresponding author: Teknologi Pengolahan Hasil Laut, Jurusan Perikanan dan Kebaharian, Politeknik Negeri Nusa Utara, Alamat : Jl. Kesehatan No. 1, Tahuna, Kab. Kepulauan Sangihe-SULUT

Email address: frets.jr@gmail.com

Published by FMIPA UNSRAT (2019) 
$67,7 \%$ dan kadar lemak 0.75\%; Tipe B dengan kadar lemak $<3 \%$ dan Tipe $\mathrm{C}$ sama seperti tepung ikan tetapi pengolahannya dilakukan secara higienis.

Umumnya semua daging ikan dapat dimanfaatkan sebagai bahan baku pembuatan KPI, tetapi ikan-ikan non ekonomis menjadi pilihan utama untuk dijadikan sebagai bahan baku. Ikan sunglir merupakan jenis ikan pelagis yang banyak dijumpai di Kabupaten Kepulauan Sangihe. Nama lokal ikan ini adalah 'mangganganu'. Menurut data DKP (2016), produksi ikan sunglir pada tahun 2015 mencapai 26,35 ton/tahun. Ikan ini belum banyak dimanfaatkan oleh masyarakat Sangihe sehingga memiliki peluang untuk dimanfaatkan sebagai bahan baku pembuatan konsentrat protein ikan. Tujuan penelitian ini adalah mengkarakterisasi fisiko-kimia konsentrat protein ikan dari daging ikan sunglir.

\section{Material dan Metode \\ Bahan utama yang digunakan dalam penelitian ini adalah ikan sunglir dan pelarut ethanol 90\%. Ektraksi Konsentrat Protein Ikan (KPI) Sunglir mengacu pada metode Rieuwpassa et al. (2018). Ikan sunglir dipreparasi untuk dipisahkan dagingnya dari kulit dan tulang. Daging ikan sunglir dilumatkan dan ditimbang. Ekstraksi menggunakan ethanol 90\% dengan perbandingan 1: $3 \mathrm{~b} / \mathrm{v}$ selama 3 jam. Selanjutnya disaring untuk memperoleh endapan. Endapan KPI dikeringkan pada oven listrik. Suhu pengeringan $\pm 45^{\circ} \mathrm{C}$ selama 8 jam. Hasil pengeringan ditepungkan dan diayak dengan saringan ukuran \pm 60 mesh. KPI kemudian dianalisis meliputi : kadar protein (AOAC 2005), kadar lemak (AOAC 2005), Kadar Air (AOAC 2005), Kadar Abu (AOAC 2005), derajat putih (Whitenessmeter) dan organoleptik bau (Soekarto dan Hubies 1982), daya serap minyak (Beuchat 1977), daya serap lemak (Beuchat 1977), densitas kamba (Wirakartakusumah et al. 1992) serta komposisi asam amino (AOAC 1995).}

\section{Hasil dan Pembahasan}

Bahan baku daging sunglir yang digunakan dianalisis proksimat yang terdiri dari protein, lemak, air dan abu. Hasil analisis dapat dilihat pada Tabel 1.

Tabel 1. Proksimat daging ikan sunglir

\begin{tabular}{|l|c|}
\hline Parameter & Persentase (\%) \\
\hline Protein & 22.72 \\
\hline Lemak & 0.72 \\
\hline Air & 74.67 \\
\hline Abu & 0.91 \\
\hline
\end{tabular}

Hasil pengujian menunjukkan bahwa ikan sunglir tergolong ikan berprotein tinggi dan berkadar lemak rendah. Kandungan protein ikan ditentukan oleh ukuran ikan (Nianda 2008) dan jenis makanan yang dikonsumsi pada perairan (Ramlah et la. 2016). Ikan dengan kadar protein 15-20\% tergolong ikan berprotein tinggi (Nurhayati 2007). Kadar lemak ikan sunglir tergolong rendah (0.72\%). Kadar lemak pada ikan dipengaruhi oleh kebiasaan makan, tingkat kematangan gonad, musim, faktor lingkungan dan sumber makanan seperti tumbuhan dan hewan (Nianda 2008 dan Ramlah et al. 2016).
Hasil ekstraksi KPI ikan sunglir dapat dilihat pada Gambar 1. Konsentrat protein yang telah diekstrak selanjutnya dikarakterisasi sifat fisiko kimia. Hasil analisis dapat dilihat pada Tabel 2 .

Gambar 1. Tepung KPI ikan sunglir

Tabel 2. Hasil analisis fisiko kimia KPI sunglir.

\begin{tabular}{|l|r|}
\hline Parameter Kimia & Jumlah \\
\hline Protein (\%) & $\underline{\mathbf{7 7 . 3 4}}$ \\
\hline Lemak (\%) & $\mathbf{1 . 2 2}$ \\
\hline Air (\%) & 9.34 \\
\hline Abu (\%) & 3.38 \\
\hline Parameter fisiko & $\underline{\mathbf{5 4 . 5 2}}$ \\
\hline Bau & 1.04 \\
\hline Derajat putih (\%) & 0.53 \\
\hline Densitas kamba (g/ml) & 2.10 \\
\hline Daya serap air (g/ml) & (aroma ikan lemah) \\
\hline Daya serap minyak (g/g) & \\
\hline
\end{tabular}

Parameter utama untuk menentukan kualitas/tipe KPI berdasarkan standar mutu KPI (FAO 1976) adalah kadar protein, kadar lemak, bau/aroma dan derajat putih. Hasil penelitian menunjukkan bahwa KPI ikan sunglir tergolong KPI tipe $\mathrm{B}$, karena memiliki kadar lemak $<3 \%$ dan aroma/bau ikan masih ada sedangkan untuk dua parameter lainnya telah sesuai standar yang ditentukan. Jenis pelarut dan lama ekstraksi sangat menentukan kualitas KPI yang dihasilkan. Pelarut ethanol dan isopropyl alcohol adalah pelarut yang biasanya digunakan dalam ekstraksi KPI (Rieuwpassa et al. 2013 dan Rieuwpassa et al. 2018). Sifat polar pelarut menyebabkan lemak tertarik dengan baik dari daging ikan selama proses perendaman (Tirtajaya et al. 2008).

Secara karakteristik kimia, KPI ikan sunglir memiliki protein yang cukup tinggi (77.34\%), lemak yang rendah (1.22\%), kadar air (9.34\%) dan kadar abu (3.38\%). Jumlah protein lebih rendah dan jumlah kadar lemak yang lebih baik dibandingkan penelitian Rieuwpassa et al. (2018) yang menghasilkan protein KPI ikan sunglir berkisar $85.43 \%$ dan lemak 3.28\%. Kadar air KPI ikan sunglir masih tinggi, hal ini dikarenakan proses pengeringan tidak begitu lama sehingga masih ada air bebas yang terikat dalam partikel protein. Rieuwpassa et al. (2018) memperoleh kadar air 6.34\% dengan lama pengeringan 24 jam pada suhu $40^{\circ} \mathrm{C}$.

Densitas Kamba diartikan sebagai perbandiangan berat/bobot bahan dengan ruang yang ditempatinya (volume). KPI ikan sunglir memiliki densitas Kamba $1.04 \mathrm{~g} / \mathrm{ml}$ artinya $1.04 \mathrm{~g} \mathrm{KPI}$ dapat mengisi ruang/volume sebesar $1 \mathrm{ml}$. Pengukuran densitas Kamba ini dimaksudkan untuk mengetahui ruang yang 
ditempati ketika bahan pangan disimpan. Selain itu, pengukuran densitas Kamba juga dapat mengindikasikan keseragaman ukuran partikel, semakin tinggi densitasnya maka partikelnya semakin seragam.

Daya serap air merupakan kemampuan bahan untuk menyerap air sedangkan daya serap minyak adalah kemampuan bahan menyerap minyak. Daya serap air KPI ikan sunglir adalah $0.53 \mathrm{~g} / \mathrm{ml}$, berarti setiap $0.53 \mathrm{~g} \mathrm{KPI} \mathrm{memiliki} \mathrm{kemampuan} \mathrm{penyerapan} \mathrm{air}$ sebesar $1 \mathrm{ml}$. Rieuwpassa et al. (2018) menyatakan kemampuan menahan air dari luar dan dalam bahan pangan disebut daya serap air. Kemampuan penyerapan air ini sangat penting untuk diketahui, terutama untuk bahan-bahan berbentuk tepung. Pada proses pengolahan bahan pangan jumlah penggunaan air sangat perlu diketahui sehingga membantu dalam proses pembentukan adonan (gelatinisasi). Daya serap minyak KPI ikan sunglir adalah $2.10 \mathrm{~g} / \mathrm{g}$, berarti setiap 2.10 gr KPI mampu menyerap 1 gr minyak. Kemampuan penyerapan minyak dan air oleh KPI disebabkan karena adanya asam-asam amino yang bersifat hidrofilik jika keadaan polar dan hidrofobik jika keadaan non polar.

Protein tersusun dari sejumlah asam-asam amino yang berikatan satu sama lain. Komposisi asam amino KPI ikan sunglir sapat dilihat pada Tabel 3.

Tabel 3. Komposisi asam amino KPI ikan sunglir

\begin{tabular}{|l|r|}
\hline \multicolumn{1}{|c|}{ Jenis asam amino } & Jumlah $(\mathrm{mg} / \mathrm{g})$ \\
\hline Serin & 14.42 \\
\hline Isoleusin & 10.10 \\
\hline Asam glutamat & 20.88 \\
\hline Fenilalanin & 8.30 \\
\hline Valin & 10.71 \\
\hline Arginin & 11.26 \\
\hline Alanin & 9.42 \\
\hline Glisin & 11.00 \\
\hline Lisin & 15.92 \\
\hline Asam aspartate & 13.05 \\
\hline Leusin & 16.48 \\
\hline Tirosin & 6.73 \\
\hline Prolin & 6.43 \\
\hline Treonin & 11.98 \\
\hline Histidin & 8.77 \\
\hline TOTAL & 175.53 \\
\hline
\end{tabular}

Berdasarkan kebutuhan oleh tubuh, asam amino dibagi menjadi asam amino essensial dan asam amino non essensial. KPI ikan sunglir memiliki 15 jenis asam amino yang terdiri dari 8 asam amino essensial yaitu isoleusin, fenilalanin, valin, arginine, lisin, leusin, treonin dan histidin; 7 asam amino non essensial yaitu serin, asam glutamat, alanine, glisin, asam aspartate, tirosin dan prolin. Leusin merupakan jenis asam amino yang memiliki jumlah paling banyak yaitu $16.48 \mathrm{mg} / \mathrm{g}$, hal ini berbeda dengan beberapa penelitian lainnya tentang KPI yang menyebutkan bahwa lisin adalah jenis asam amino terbanyak pada KPI (Sathivel et al. 2009; Rieuwpassa et al. 2013; Wiharja et al. 2013; Rieuwpassa et al. 2018).

Asam amino yang dimiliki oleh KPI ikan sunglir dapat dimanfaatkan sebagai bahan substitusi terutama terhadap bahan-bahan makanan yang rendah protein. KPI sunglir juga memiliki asam amino arginine dan histidine yang sangat bermanfaat bagi bayi dan balita. Menurut Rieuwpassa et al. (2019), asam amino arginine dan histidine adalah asam amino yang tidak dapat diproduksi oleh bayi dan balita sehingga harus disuplay dari luar. Ketika dewasa arginine dan histidine usdah dapt diproduksi oleh tubuh.

\begin{abstract}
Kesimpulan
Berdasarkan hasil penelitian maka dapat disimpulkan bahwa KPI yang diekstrak dari daging ikan sunglir tergolong KPI tipe B dengan komposisi kimia protein $77.34 \%$, lemak $1.22 \%$, air $9.34 \%$ dan abu 3.38\% dan karakteristik fisiko meliputi derajat putih $54.52 \%$, bau/aroma ikan lemah, densitas Kamba 1.04 $\mathrm{g} / \mathrm{ml}$, daya serap air $0.53 \mathrm{~g} / \mathrm{ml}$ dan daya serap minyak $2.10 \mathrm{~g} / \mathrm{g}$ serta memiliki 8 jenis asam amino essensial. KPI sunglir dapat dijadikan sebagai sediaan protein dan dapt dimanfaatkan sebagai bahan substitusi, fortifikasi dan penambahan pada produk-produk yang rendah protein. Perlu dilakukan penelitian terkait aplikasi KPI kedalam bahan pangan.
\end{abstract}

\section{Daftar Pustaka}

[AOAC] Association of Official Analitical Chemist. 2005. Official methods of analysis of the association of official analytical chemist 18th edition. Gaithersburg (US): AOAC International

[AOAC] Association of Official Analytical Chemists. 1995. Official methods of analysis the the association of official analytical chemist 16th edition. Virginia (US): AOAC International.

Beuchat, L. R. 1977. Functional and electrophoretic characteristics of succinylated peanut flour protein. J. Agric. Food Chem. 25(6): 258-261.

Ibrahim, M. S. 2009. Evaluation of production and quality of salt-biscuits supplemented with fish protein concentrate. World J. Dairy Food Sci. 4(1):28-31

Nianda, T. 2008. Komposisi protein dan asam amino daging ikan gurami (Osphronemus gouramy)ada berbagai umur panen. Skripsi. Program Studi Teknologi Hasil PerikananFakultas Perikanan dan IImu Kelautan Institut Pertanian Bogor.

Nurhayati, T., Salamah, E., dan Hidayat, T. 2007. Karakteristik hidrolisat protein ikan selar (Caranx leptolepis) yang diproses secara enzimatis. Journal Buletin Teknologi Hasil Perikanan. X (1): 23-34.

Ramlah, E., Soekendarsi, Z., Hasyim., dan Hasan, M. S. 2016. Perbandingan kandungan gizi ikan nilaOreochromis niloticus asal Danau Mawang Kabupaten Gowa dan Danau Universitas Hasanuddin Kota Makassar. Jurnal Biologi Makassar (Bioma). 1 (1): 39-46

Rieuwpassa, F. J., Santoso, J., dan Trilaksani, W. 2013. Characterization Of Functional Properties Fish Protein Concentrate Of Skipjack Roe (Katsuwonus pelamis). J. Ilmu dan Teknologi Kelautan Tropis, Vol. 5 (2) : 299-309 
Rieuwpassa, F. J., Karimela, E. J., dan Lasaru, D. C. 2018. Karakterisasi Sifat Fungsional Konsentrat Protein Ikan Sunglir (Elagatis bipinnulatus). Jurnal Teknologi Perikanan dan Kelautan 9 (2) : 177-183

Rieuwpassa, F. J., Santoso, J., dan Trilaksani, W. 2019. Aplikasi konsentrat protein telur ikan cakalang dalam formulasi makanan bayi pendamping ASI. Jurnal Pengolahan Hasil Perikanan Indonesia. 22(1): 100-110.

Sathivel, S., Yin, H., Bechtel, P. J., dan King, J. M. 2009. Physical and Nutritional Properties of Catfish Roe Spray Dried Protein Powder and Its Application in an Emulsion System. J. Food Eng. 95(1) : 76-81. DOI: 10.1016/j. jfoodeng.2009.04.011.

Soekarto, S. T., dan Hubeis, M. 1982. Metodologi Penelitian Organoleptik. Bogor (ID): Institut Pertanian Bogor

Wiharja, S. Y., Santoso, J., dan Yakhin, L. A. 2013. Utilization of Tuna and Red Snapper Roe Protein Concentrate as Emulsifier in Mayonnaise. Journal of Food Science and Engineering. 3 : 678-687.

Wirakartakusumah, M. A., Abdullah, K., dan Syarif, A, M. 1992. Sifat Fisik Pangan. Bogor (ID): Institut Pertanian Bogor 